\title{
現地海岸における飛砂量の高頻度観測 \\ High-frequency Field Measurements of Aeolian Sand Transport Rate at a Beach
}

\author{
有働恵子 ${ }^{1}$
}

\section{Keiko UDO}

\begin{abstract}
This study conducted field observations in terms of the number of wind-blown sand impacts and wind velocity in the period of 22 September-2 December 2005 at an open ocean beach in Japan, in order to investigate variation of the wind-blown sand transport rate. Measured transport rate was calculated using the number of wind-blown sand impacts and compared to the rate estimated from the wind velocity using Bagnold's, Kawamura's, and Owen's equations. During the measurement period, the rate estimated using Owen's equation was relatively good agreement with the measured rate and the other equations overestimate the measured rate. The rate estimated using Kawamura's equation from hourly wind data obtained at off-site significantly overestimates the measured rate more than one order. Further knowledge about the actual aeolian sand transport should be accumulated in the field.
\end{abstract}

\section{1. 緒言}

飛砂は砂漠化や海岸に隣接する農地における塩害およ び道路への堆砂の原因になるなど，様々な分野で深刻な 問題を引き起こしている．飛砂に関する問題を扱う際に は飛砂量を把握することが重要であるものの, 現地にお ける計測が容易でないことから飛砂量に関する連続的な 長期実測デー夕は得られていない。 また, 現地の飛砂量 推定では通常風洞実験において得られた経験式に 1 時間 毎の10分間平均風速デー夕を与えることにより推定され ているが，この推定值について十分な検証はなされてい ない.

1990年代の情報技術の発達に伴い，飛砂に関しても計 測機器が開発され, 現地において高頻度で計測を行うこ とが可能になってきた. Stockton・Gillette（1990）が飛 砂カウンター（Sensit）を開発したのを皮切りに, Bauer・ Namikas（1998）がトラップ型高頻度飛砂量計を, 保坂ら（2004）がSensitと同様の飛砂カウンターを独自 に開発し，2000年代に入ってからは現地において取得さ れた短期デー夕の解析結果も報告されるようになってい る. 飛砂カウンターはセンサー部（圧電振動子）への飛 砂の衝突数をカウントするものであり, トラップ型高頻 度飛砂量計は捕砂器に捕捉された砂量を数秒毎に計測し 飛砂量を算定するものである. 飛砂カウンターには使用 制限がないのに対し, 飛砂量計は許容量以上の砂が機器 内に貯留すると計測不能となる.

有働（2007，2008）は2005年1月12日～16日の茨城県 波崎海岸における荒天時を含む飛砂の高頻度観測デー夕 を用いて飛砂の限界摩擦速度㧍よび飛砂質量フラックス に関する解析を行った，その結果，平均風速が大きくな

1 正会員 博 (工) 東北大学助教 災害制御研究センター

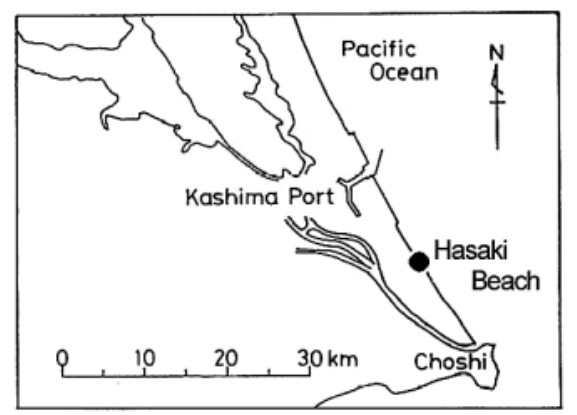

図-1＼cjkstart観測地の位置

るにつれて飛砂の限界摩擦速度は小さくなること, 風向 の岸沖方向から沿岸方向への変化および降雨により飛砂 フラックスはそれぞれ1オーダー程度減少することなど 既存の知見と矛盾しない飛砂特性が実証され, 飛砂カウ ンターを用いた現地の飛砂状況の把握が可能であること が示された。

本研究では, 現地における飛砂量を簡便に計測する手 法を開発することを目的とし, 超音波式風向風速計およ び飛砂カウンターを用いて約 2 ケ月間のデータを $1 \mathrm{~Hz}$ 取得し, 計測值より算定される飛砂量と経験式より算定 された飛砂量とを比較して, その差異について調べた.

\section{2. 現地海岸における飛砂計測の概要}

鹿島灘に面する茨城県波崎海岸において, 瞬間風向風 速および飛砂粒子数の計測を行った（有働，2007，2008； 図-1). 波崎海岸は前浜勾配が $1 / 50$ 程度の遠浅の海岸で, 計測点は平均汀線より $90 \mathrm{~m}$ 陸側の後浜である. 計測期間 は2005年9月 22 日〜 12 月 6 日で, 計測期間中の計測点に おける地表面の砂の中央粒径 $d_{50}$ は $0.2 \mathrm{~mm}(2.3 \phi)$ 程度で あった。

瞬間風向風速および飛砂粒子数を計測する超音波式風 


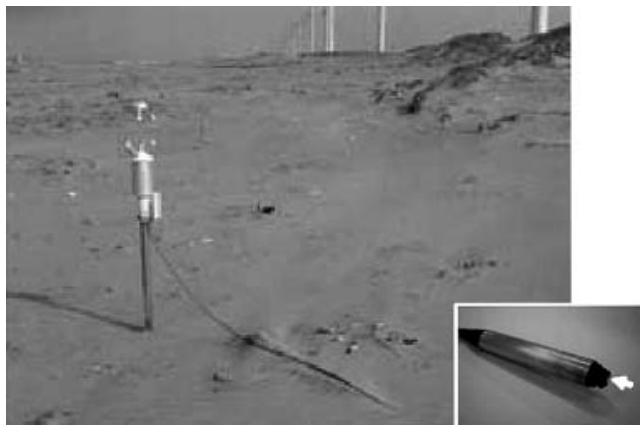

図-2 計測機器の設置状況

(白枠内：圧電飛砂計, 白矢印：圧電振動子)

向風速計および圧電飛砂計の設置状況を図-2に示す。瞬 間風向風速は, 超音波式風向風速計（Delta OHM 社,

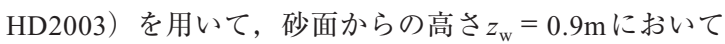
計測した。風向は $\mathrm{N}$ 方向を 0 度として時計回りに正とし た. 150〜330度のとき陸風となる.

圧電飛砂計（ud-101；保坂ら，2004）は, 圧電振動子 に飛砂が衝突する際に生じるノイズを利用して $10 \mathrm{kHz}$ 飛砂数を計測し，1Hzで飛砂数を記録する．各サンプリ ング時間における飛砂の有無を判断し，飛砂がある場合 をカウントすることから，1秒当りの最大カウント数は 10000 である。計測システム上，複数の飛砂が同時に衝 突した場合のカウント数は 1 となるが，久保田ら（2007） の結果によればサンプリング周波数が $4 \mathrm{kHz}$ 以上であれば 衝突信号数は概ね一定となる。本センサーは単一方向の 飛砂量のみ計測可能であり, 衝突角が \pm 45 度以内であれ ば概ね等しい衝突数が得られることから (Udo et al., 2008），4方向に設置した. 各センサーの観測開始時の地 盤からの設置高さは $z_{\mathrm{s}}=0.04 \mathrm{~m}$ であるが, 長期的には設 置高さが大きく変化するため, 各センサーの地盤からの 高さについてもほぼ毎日計測した。

風向風速および飛砂数デー夕は $1 \mathrm{~Hz}$ で取得し, デー夕 ロガー（National Instruments社のcFP-2000）に記録した。 波崎海洋研究施設（HORS）より直接電力を供給し，齐 ットワーク経由で 12 時間毎にロガーに蓄積されたデータ を収集することにより，メンテナンスフリーで半永久的 にデータを収集することが可能なシステムとなってい る.これらのデータに加えて, 瞬間風向風速データのキ ヤリブレーションのために波崎海岸の標高 $10 \mathrm{~m}$ 地点で取 得された 1 時間毎の風向風速デー夕を，また，土壤水分 量の飛砂への影響を考慮するために銚子気象台における 降水量データを使用した。

飛砂数 $n\left[\mathrm{~s}^{-1}\right]$ を飛砂フラックス $q_{\text {Sensor }}\left(z_{\mathrm{s}}\right)\left[\mathrm{kg} \mathrm{m}^{-2} \mathrm{~s}^{-1}\right]$ に変 換する際には，有働（2008）と同様に

$$
q_{\text {Sensor }}\left(z_{s}\right)=\frac{2 \rho_{s} d^{3} n}{3 d_{P S}{ }^{2} t_{0}}
$$

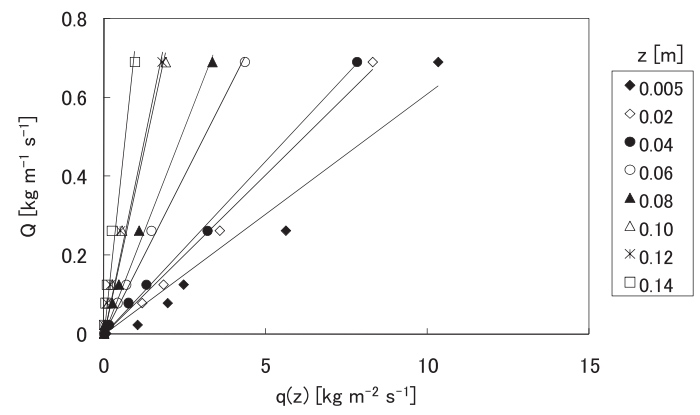

図-3 砂粒径 $d_{50}=0.25 \mathrm{~mm}$ の場合の全飛砂量 $Q$ と砂面からの高 さ $z$ における飛砂フラックス $q(z)$ との関係 (Hotta ら (2006) 参照)

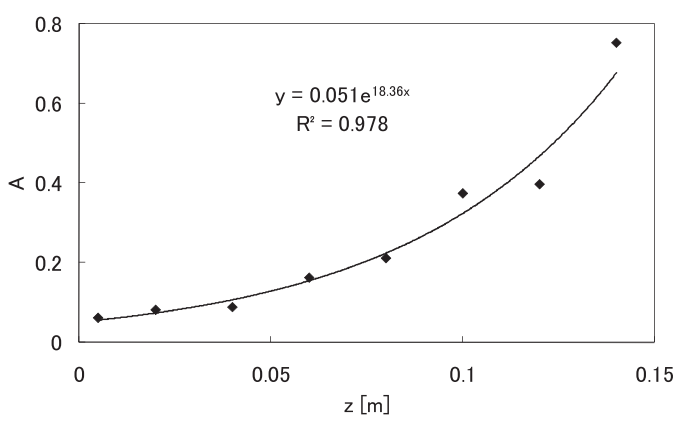

図-4 砂面からの高さ $z$ と係数 $A$ との関係

を用いた.ここで, $d$ : 砂の中央粒径, $\rho_{s}$ : 砂の密度 (= $\left.2.65 \times 10^{3} \mathrm{~kg} / \mathrm{m}^{3}\right), d_{P S}$ : 飛砂計センサー部の直径（= $0.012 \mathrm{~m}), t_{0}$ : 計測時間 $(=1 \mathrm{~s})$ である. $d_{50}=0.25 \mathrm{~mm}$ の とき圧電飛砂計による計測值 $q_{\text {Sensor }}(z)$ とトラップによる 計測值 $q(z)$ の間には比例関係（決定係数 $R^{2}=0.90 ）$ が認 められる.

$$
q(z)=10.57 q_{\text {Sensor }}(z)
$$

さらにHottaら（2006）の実験結果より， $0.17 \backslash \mathrm{m} / \mathrm{s} \leqq u_{*} \leqq$ $1.77 \mathrm{~m} / \mathrm{s}$ および $0.14 \mathrm{~mm} \leqq d_{50} \leqq 0.68 \mathrm{~mm}$ の範囲において，全 飛砂量 $Q\left[\mathrm{~kg} \mathrm{~m}^{-1} \mathrm{~s}^{-1}\right]$ と飛砂フラックス $q(z)$ は比例関係に ある (図-3). $d_{50}=0.25 \mathrm{~mm}$ のとき, その決定係数 $R^{2}$ は $z=0.005,0.02,0.04,0.06,0.08,0.10,0.12$ ，ならびに $0.14 \mathrm{~m}$ のとき, ぞれぞれ $0.96,0.99,1.00,1.00,0.99$, $0.98,0.97$, ならびに 0.97 となり, 特に $z=0.02 \sim 0.08$ のと き $R^{2}$ 值が大きい.ここで,

$$
Q=A q(z)
$$

とおき, $A$ と $z$ との関係を調べると,これらの間には

$$
A=B \exp (C z)
$$

の関係が認められる (図-4). $d_{50}=0.25 \mathrm{~mm}(2.0 \phi)$ のと き $B=0.052$ および $C=18.36$ であるから, 式 (2) 〜 (4) より 


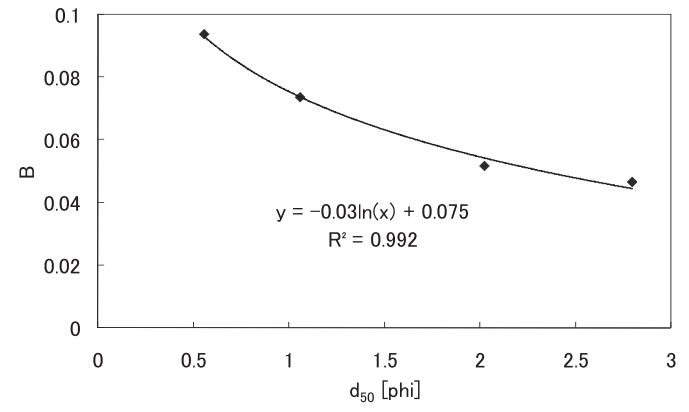

図-5 砂粒径 $d_{50}$ と係数 $B$ との関係

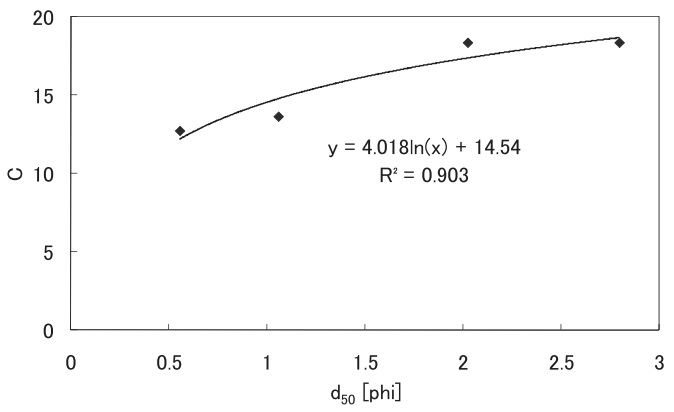

図-6 砂粒径 $d_{50}$ と係数 $C$ との関係

$$
Q=0.052 \exp (18.36 z) q(z)
$$

が得られ， $z_{\mathrm{s}}$ および $n$ のデー夕が取得できれば現地で 時々刻々と変化する $Q$ を推定することが可能になる． $B$ およびCは粒径に依存する係数で粒径が小さくなるにつ れてその值は収束する傾向にある(図-5および図-6参照). 有働ら（2005）によれば対象領域の底質粒径変化は小さ いことから $d_{50}$ は $0.2 \mathrm{~mm}$ 程度で一定とし, この粒径に最も 近い $d_{50}=0.25 \mathrm{~mm}(2.0 \phi)$ の式（1）および（5）を用い て $Q$ を推定した。得られた值は，10分間平均值に換算し Bagnold（1941），河村（1951），ならびにOwen（1964） の飛砂量式

$$
\begin{aligned}
& Q_{B}=c_{B} \sqrt{\frac{d}{D}} \frac{\rho}{g} u_{*}^{3} \cdots \ldots \ldots \ldots \ldots \ldots \ldots . . . \\
& Q_{K}=c_{K} \frac{\rho}{g}\left(u_{*}-u_{*_{t}}\right)\left(u_{*}+u_{*_{t}}\right)^{2} \ldots \\
& Q_{O}=c_{O} \frac{\rho}{g} u_{*}\left(u_{*}-u_{*_{t}}\right)\left(u_{*}+u_{*_{t}}\right)
\end{aligned}
$$

と比較した。ここで, $\rho$ : 空気の密度 $\left(=1.226 \mathrm{~kg} / \mathrm{m}^{3}\right)$, $g$ : 重力加速度 $\left(=9.81 \mathrm{~m} / \mathrm{s}^{2}\right), u_{*}$ : 摩擦速度, $u_{*_{t}}$ : 限界 摩擦速度, $c_{B}$ : 係数 $(=1.8), c_{K}$ : 係数 $(=2.78)$, ならび に, $c_{O}$ : 係数 $\left(=0.25+w_{0} / 3 u_{*}\right)$ である. $d=0.2 \mathrm{~mm}$ の場 合の沈降速度 $w_{0}$ は, Rubey式（1933）

$$
w_{0}=\sqrt{(s-1) g d}\left(\sqrt{\frac{2}{3}+\frac{36 v^{2}}{(s-1) g d^{3}}}-\sqrt{\frac{36 v^{2}}{(s-1) g d^{3}}}\right)
$$

より $1.3 \mathrm{~m} / \mathrm{s}$ とした.ここで, $s$ は砂の流体中比重 $(=\sigma / \rho)$, $v$ は動粘性係数である。 $u_{*}$ は有働（2008）と同様に

$$
\begin{aligned}
& u_{*}=\frac{\kappa u}{\ln \left(z / z_{0 s}\right)} \\
& z_{0 s}=c_{0} \frac{u_{*}^{2}}{2 g}
\end{aligned}
$$

より， $u^{*}{ }_{t}$ は Bagnold（1941）の限界摩擦速度式

$$
u_{*_{t}}=A \sqrt{\frac{\rho_{s}-\rho}{\rho} g d}
$$

で算定した。ここで $\kappa$ : カルマン係数 $(=0.4), u$ : 風速, $z$ : 風速計の砂面からの高さ $(=0.9 \mathrm{~m}), d$ : 砂の粒径, $z_{0}$ : 粗度高さ, $A$ : 定数 $(=0.1), c_{0}$ : 定数 $(=0.16$; Raupach, 1991), $\rho_{s}$ : 砂の密度 $\left(=2650 \mathrm{~kg} / \mathrm{m}^{3}\right)$ である.

\section{3. 計測結果}

波崎海岸で取得された風向風速および飛砂数, 銚子地 方気象台で取得された降水量, ならびに飛砂計の砂面か らの高さの時系列デー夕を図-7に示す。実際にデータを 取得できた期間は2005年9月22日 0:00〜 10月27日 6:14, 11月 14 日 14:18〜 12月 6日 7:11で，ネットワークの不具 合により 10 月 27 日〜 11月 14 日のデータが欠測となった. 波崎海岸で取得された風向風速データについては, 瞬間 風速が $50 \mathrm{~m} / \mathrm{s}$ を越えた場合, あるいは, 観測地への低気 圧の接近が認められないにもかかわらず風速が $18 \mathrm{~m} / \mathrm{s}$ を 超えた場合には異常值と判断し欠測とした。 センサーの 砂面からの高さは-3〜 82mmに変化していた. 負の值は センサーが埋没していたことを示す. 降雨量の最大值は $9 \mathrm{~mm} / \mathrm{hr}$ であった.

観測期間中, 台風 17 号の接近により最大平均風速 $23 \mathrm{~m} / \mathrm{s}$ を記録した. 飛砂数が最大となるセンサーの向き と風向は概ね一致し, また, 風速が大きい場合に飛砂数 も大きくなっており, 妥当な結果が得られた.

\section{4. 計測飛砂量と既存の提案式を用いて推定した 飛砂量との比較}

飛砂数が最大となるセンサーの $n$ を用いて, 式（5）よ り求めた $Q$ と, 式（7）および（8）を用いて求めた推定 飛砂量 $Q_{K}$ および $Q_{O}$ との比較を図-8に示す（時系列につ いては図-7参照). $Q$ を求める際の $z$ としては $z_{s}$ を線形補 間したものを与えた. $Q_{O}<Q_{B}<Q_{K}$ の関係にあり, $Q_{B}$ は $Q$ に対する $Q_{K}$ および $Q_{O}$ の関係と定性的に等しいことか ら図を省略した. 河村式の係数 $c_{K}$ は条件により $1.0 \sim 3.1$ の範囲で変化することが報告されているが, 本計測の場 合には $c_{K}$ を 0.5 とすれば $Q_{K}$ は $Q_{O}$ と概ね一致する.

$Q>0.01 \mathrm{~kg} / \mathrm{m} / \mathrm{s}$ の場合にはOwen式（1964）で比較的精度 よく推定できるものの, いずれの場合にも $Q<0.01 \mathrm{~kg} / \mathrm{m} / \mathrm{s}$ の場合には過大評価となった。 9 月 22 日 0:00〜 12 月 3 日 


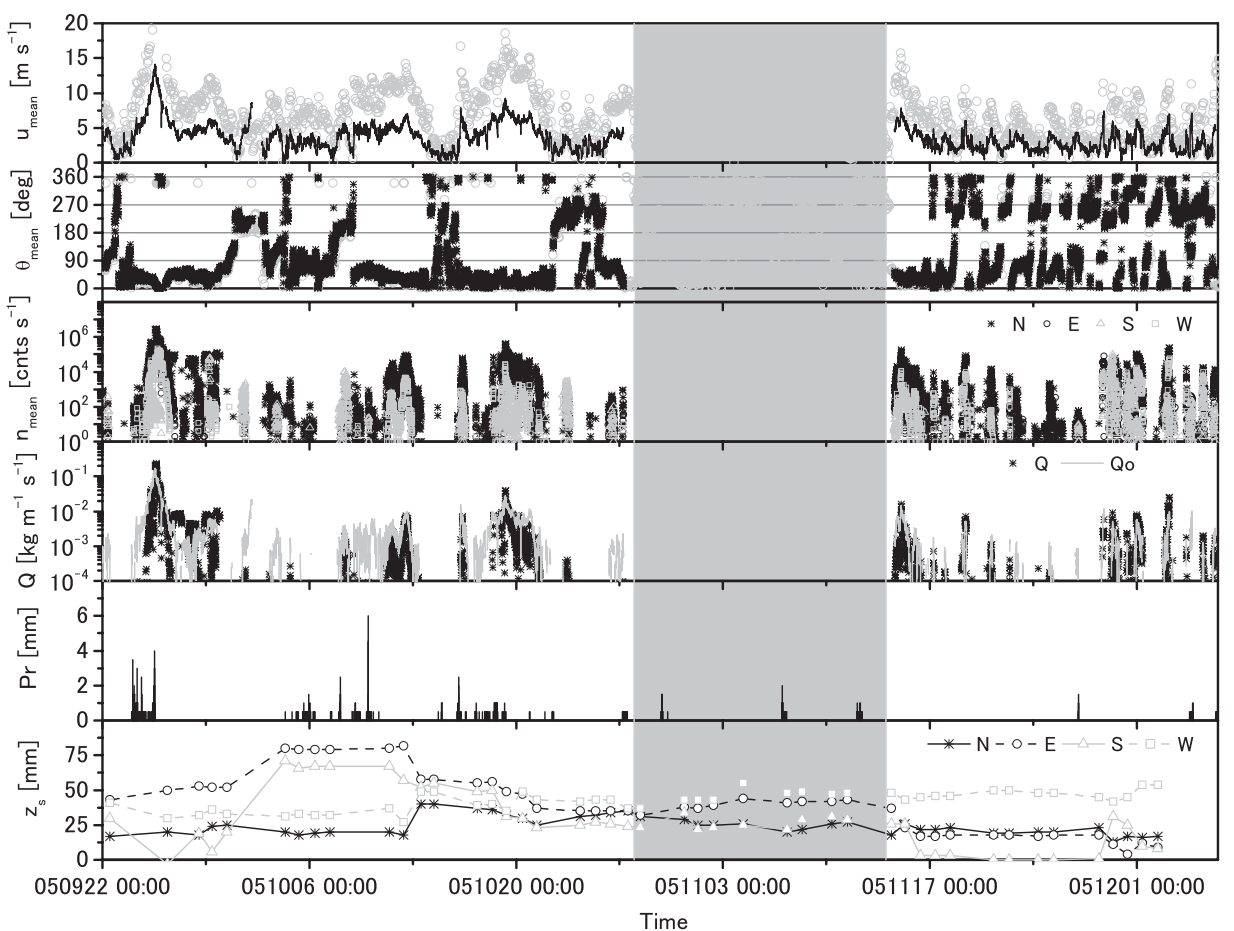

図-7 10 分間平均風速 $u$, 平均風向 $\theta$, 飛砂粒子数 $n$, 計測飛砂量 $Q$ および推定飛砂量 $Q_{O}$, 降水量 $P_{r}$, ならびに飛砂センサーの砂面 からの高さ $z_{s}$ の時系列. 平均風向風速の灰色プロットはHORS栈橋上標高 $10 \mathrm{~m}$ 地点で取得されたデータを，灰色ハッチ部分は $u, \theta$, ならびに $n$ の欠測期間を示す.

0:00の, 久測期間, 異常值観測期間，ならびに降雨時（降 雨終了後 2 時間以内は降雨時と定義）を除く期間の積算質 量飛砂量を積算し積算体積飛砂量に換算すると, $Q_{B}=$ $9.7 \mathrm{~m}^{3} /(\mathrm{m} \cdot 69.7$ days $), Q_{K}=18.0 \mathrm{~m}^{3} /(\mathrm{m} \cdot 69.7$ days $)$, ならび に $Q_{O}=4.5 \mathrm{~m}^{3} /(\mathrm{m} \cdot 69.7 \mathrm{days})$ となった。さらに, 風向を 用いてこれらの積算值を岸沖方向および沿岸方向の体積 飛砂量に換算し積算したところ，岸沖方向については $Q_{B}=6.6 \mathrm{~m}^{3} /(\mathrm{m} \cdot 69.7 \mathrm{days}), Q_{K}=12.3 \mathrm{~m}^{3} /(\mathrm{m} \cdot 69.7$ days $)$, な らびに $Q_{O}=3.0 \mathrm{~m}^{3} /(\mathrm{m} \cdot 69.7$ days $)$ （陸向きを正）となり， 沿岸方向については $Q_{B}=5.4 \mathrm{~m}^{3} /(\mathrm{m} \cdot 69.7 \mathrm{days}), Q_{K}=$ $10.5 \mathrm{~m}^{3} /(\mathrm{m} \cdot 69.7$ days $)$ ならびに $Q_{O}=2.5 \mathrm{~m}^{3} /(\mathrm{m} \cdot 69.7$ days $)$ （銚子方向を正）となった．総飛砂量, 岸沖飛砂量, なら びに沿岸飛砂量の計測值 $Q=2.3,1.5$ ，ならびに $1.5 \mathrm{~m}^{3} /(\mathrm{m} \cdot 69.7 \mathrm{days})$ はOwen式を用いた推定值に最も近 い值となるものの，いずれも 1.6 倍以上の值となり過大評 価であった。

ここで求めた $Q_{B}, Q_{K}$, ならびに $Q_{O}$ は観測地点付近の砂 面から $0.9 \mathrm{~m}$ の地点において計測された 10 分間平均風速を 用いて推定された。しかしながら，我が国における現地 の飛砂量推定では，通常対象領域に最も近い気象観測所 で取得された毎正時の 10 分間平均風向風速デー夕を用い てZingg式（1953）および河村式（1951，式（7)）よりu* および $Q_{K}$ を推定される場合が多い（土木学会編，1999；

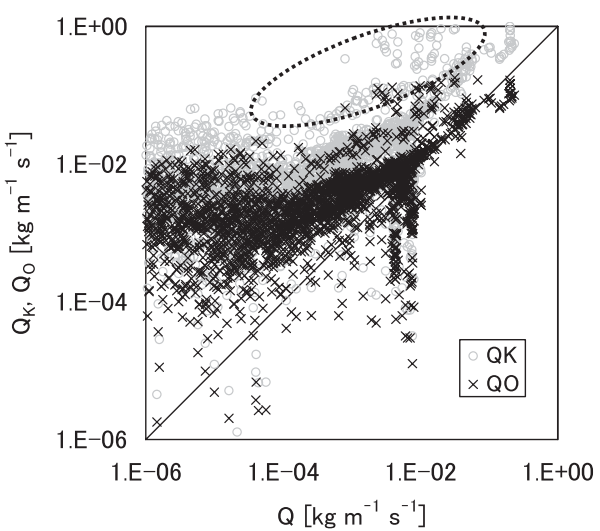

図-8 $n$ より求めた計測飛砂量 $Q$ と推定飛砂量 $Q_{K}$ および $Q_{O}$ と の関係 (10分間平均値). 点線円内は降雨時のデー夕を 示す.

佐藤ら，2008)。よって次に, 波崎海岸の HORS栈橋上標 高 $10 \mathrm{~m}$ 地点で取得された毎正時の 10 分間平均風向風速デ 一夕を用いて同期間の $Q_{K}$ の推定を行った. $Q_{K}$ の積算值は $30.9 \mathrm{~m}^{3} /(\mathrm{m} \cdot 69.7$ days $)$ となり, 計測值 $Q=2.3 \mathrm{~m}^{3} /(\mathrm{m}$ ・ 69.7days) を大幅に上回った。岸沖・沿岸方向について も, $Q_{K}=22.2 \mathrm{~m}^{3} /(\mathrm{m} \cdot 69.7$ days $)$ および $Q_{K}=17.2 \mathrm{~m}^{3} /(\mathrm{m}$ ・ 69.7days) となり, 1オーダー程度の過大評価となった。

本計測期間においては, Bagnold式，河村式，ならびに 
Owen式のいずれを用いた場合にも $Q<0.01 \mathrm{~kg} / \mathrm{m} / \mathrm{s}$ の場合 の推定飛砂量は計測值より過大評価となった。この主な 原因としては，砂面の含水比の影響が挙げられる。さら に有働（2008）が指摘しているように風向によっては風 上側の砂堆・砂丘等による飛砂捕捉や，これによる fetch の減少により飛砂量が減少する。また, 図-8にみられた データのばらつきは降雨および風向変化の影響を受けた ものと考えられる.積算飛砂量の算定においては降雨時 のデー夕を排除したが，強風時には降雨があっても砂面 の湿った砂が剥ぎ取られること (blowout) により大量の 飛砂が発生する場合があることを考慮する必要がある.

通常用いられる手法（Zingg 式抢よび河村式）により 標高 $10 \mathrm{~m}$ 地点における毎正時の風向風速デー夕を用いて 推定したところ, 推定精度は1オーダー程度に低下した。 この最大の原因は, Zingg式は風速が大きい場合に $u^{*}$ を 大幅に過小評価してしまうこと，および，風速計測地点 は飛砂量推定地点と同一の風場内になく風速分布の対数 則が成立しないことにある．また，毎正時のデー夕を用 いる際，短時間の一時的な強風イベントを捉えた場合に は過大評価に，捉えなかった場合には過小評価になって しまう。

今回のセンサー設置法では, 飛砂計の存在により飛砂 計付近の風場が変化して侵食抒よび堆積が生じたものの 風上側では侵食, 風下側で堆積する傾向にあったため, 飛砂方向と一致するセンサーが埋没することはなかっ た．設置方法によっては埋没により飛砂が生じていても 検知できない場合や過剩に検知してしまう場合があるた め注意を要する.

\section{5. 結論}

現地海岸において, 圧電飛砂計を用いて風向風速, 飛 砂粒子数, ならびに飛砂センサーの設置高さを計測し, 飛砂粒子数およびセンサー設置高さを用いて算定される 計測飛砂量と平均風速より既存の飛砂量式を用いて算定 される推定飛砂量とを比較したところ, 本計測において はOwen式を用いればトータルとしては同オーダーの精 度で飛砂量の推定が可能であった. 計測飛砂量の変化特 性は既存の知見と一致しており, 飛砂センサーを用いた 飛砂量の有用な計測手段が提案された。一方, 本計測期 間に打いて通常用いられる飛砂量推定手法, すなわち, 標高 $10 \mathrm{~m}$ 地点で毎正時に取得される風速デー夕より Zingg式および河村式を用いて飛砂量を推定したところ, 推定精度は 1 オーダー程度となった. 今後様々な条件下 における観測デー夕を蓄積し，現地における飛砂の実態 を把握することが必要とされる.
謝辞：現地観測においては, 独立行政法人港湾空港技術 研究所 海洋 - 水工部 漂砂研究室 (現 沿岸環境研究領域 沿岸土砂管理研究チーム) にご協力頂いた. 日本大学 堀 田新太郎教授および久保田進教授には実験デー夕を提供 していただいた。本研究は, 科学研究費補助金 (若手研 究（B） 16760417, 代表者：有働恵子）の援助を受けて 行われた。記して謝意を表する。

\section{参 考 文 献}

有働恵子・山脇秀仁・伊東啓勝 (2005)：後浜の地形および底 質粒径変化に及ぼす汀線変化の影響, 海岸工学論文集, 第 52 巻, pp. 511-515.

有働恵子（2007）: 飛砂の限界摩擦速度に関する現地観測, 海 岸工学論文集, 第 54 卷, pp. 536-540.

有働恵子（2008）：圧電飛砂計を用いた飛砂フラックスの現地 観測, 海岸工学論文集, 第 55 巻, pp. 551-555.

河村龍馬 (1951)：飛砂の研究, 東大理工研報告, No. 5, pp. 95-112.

久保田進・保坂幸一・田村貴史（2007）：圧電振動子を用いた 飛砂量計の開発（2）－高速度カメラによる飛砂衝突状況 の可視化-, 日本大学理工学研究所所報, 第 115 号, pp. 141-149.

佐藤慎司・上谷昌史・小越千春・橋本 新 (2008)：航空レー ザー測量を用いた飛砂量推定に関する研究, 海岸工学論 文集, 第 54卷, pp. 546-550.

土木学会編 (1999)：水理公式集, pp.520-521.

保坂幸一・鵜飼正志・久保田進・小栗保二（2004）：圧電振動 子に上る飛砂粒子数の計測, 海洋開発論文集, 第 20 卷, pp. 1091-1096.

Bagnold, R. A. (1941): The Physics of Blown Sand and Desert Dunes, Methuen, London, $265 \mathrm{p}$.

Bauer, B. O. and S. L. Namikas (1998): Design and field test of a continuously weighing, tipping-bucket assembly for aeolian sand traps, Earth Surface Processes and Landforms, Vol. 23, pp. 1173-1183.

Hotta, S., S. Kubota, N. Nakamura and K. Hosaka (2006): Wind tunnel study of vertical distribution of sand transport rate by wind, Proceedings of the 30th International Conference on Coastal Engineering, ASCE, pp. 2604-2616.

Owen, P. R. (1964): Saltation of uniform grains in air, Journal of Fluid Mechanics, Vol. 20, pp. 225-242.

Raupach, M.R. (1991): Rough-wall turbulent boundary layers, Applied mechanics reviews, Vol. 44, pp. 1-25.

Rubey, W. W. (1933): Settling velocities of gravel, sand, and silt particles, American Journal of Science, Vol. 25, pp. 325-338.

Stockton, P. H. and D. A. Gillette (1990): Field measurement of the sheltering effect of vegetation on erodible land surfaces, Land degradation \& rehabilitation, Vol. 2, pp. 77-85.

Udo K., Y. Kuriyama and D. W. T. Jackson (2008): Observations of wind-blown sand under various meteorological conditions, Journal of Geophysical Research, Vol.113, F04008, doi: 10.1029/2007JF000936.

Zingg, A. W. (1953): Wind tunnel studies of the movement of sedimentary material, Proceedings of 5th Hydraulic Conference, Bulletin 24, pp. 111-135. 